\title{
An Unequal Clash: \\ The Lake Seamen's Union, the Lake Carriers' Association, and the Great Lakes Strike of 1909
}

\section{Matthew Lawrence Daley}

\begin{abstract}
La grève des Grands Lacs de 1909 a été le point culminant d'une lutte de plusieurs décennies entre les marins syndiqués et la Lake Carriers' Association. Les syndicats maritimes s'étaient efforcés de résoudre les problèmes d'identité, d'autorité et de solidarité depuis les années 1870. À la suite d'une défaite face aux travailleurs en 1901, les propriétaires de navires ont transformé leur association informelle en fédération capable de mettre en cuvre des politiques uniformes pour l'ensemble de ses membres. La défaite des travailleurs lors de la grève de 1909 est née de trois grèves précédentes (1901 à 1906); ensemble, ces conflits ont transformé l'industrie des Grands Lacs et permis aux marins de jouer un rôle dans le système industriel désormais transformé en société.
\end{abstract}

The Great Lakes Strike of 1909 drew together all the factors that had been transforming the Lakes maritime industry during the prior two decades and produced a reshaped environment where sailors operated as components within a fully integrated industrial system. The strike stood as a breaking point between two eras, that of the independent and skills-based sailors as defined by sailing ships and small companies, and the corporate world of steel ships and intensive bulk freight commodity transportation. For vessel owners these same changes had shifted the industry into a high-volume, low-margin operation tied to expensive specialized equipment.

Understanding the 1909 strike requires reviewing events and decisions that began years earlier. This examination can be framed around the series of questions. How did tensions between traditional and new steam sailors foster divisions that would undermine union solidarity? How did the emerging Lake Carriers'

The Northern Mariner / Le marin du nord, XVIII, No. 2 (Spring 2018), 119-38 
Association, the unified owners' organization, use welfare capitalism to strengthen owner unity and offer a controlled alternative to sailor unions? And what was the impact of three major strikes between 1901 and 1906 in sharpening labour divisions that would play out during the 1909 strike? These issues combined to create the conditions that led to the Great Lakes strike.

It is important to note that the 1909 strike was not a clash of equals; rather it demonstrated a decisive shift in power away from sailors to owners that continued for the next half century. The Lake Carriers' Association, maritime labour, and the 1909 strike have received only limited scholarly and popular attention. ${ }^{1}$ Thus a critical understanding of the interactions between labour and corporate entities remains elusive. unexamined. Yet these factors taken together provide a broader understanding of the Great Lakes Strike and its significance in the region's history.

\section{From Sail to Steam: Rival Unions and Fragmentation}

Sailors had unionized since the 1860s with limited success. These efforts created small assemblies of workers at individual ports throughout the Great Lakes. The definition of a sailor came from the apprenticeship model of skill and craft: the ability to handle lines, manage rigging, trim cargo, and a host of other skills learned through long practice. This fostered not only great pride but also a shared identity. The long decline of sail in the years after the American Civil War and the growing number of steamships created strong divisions on the Lakes.

Steam-powered ships created new categories of sailors. Deckhands, though called able-bodied seamen, had different certifications and appeared to traditional sailors as less skilled. Engineers tended to the increasingly sophisticated steam engines, allowing even those ships equipped with sails to need them only in emergencies. Engines also required oilers, water tenders, coal passers, and firemen to keep steam up and the mechanical parts working and they had only limited responsibilities beyond their engine room work. ${ }^{2}$

These new men entered a community that faced severe challenges to its autonomy and identity. Captains, often as builder-owner-operators of their vessels, had managed nearly all aspects working alongside mates and seamen alike. This

1 Henry Elmer Hoagland, Wage Bargaining on the Vessels of the Great Lakes (Urbana: University of Illinois, 1917); Charles P. Larrowe, Maritime Labor Relations on the Great Lakes (East Lansing Mich.: Michigan State University Labor and Industrial Relations Center, 1959); Bertram B. Lewis and Oliver T. Burnham, "Lake Carriers' Association," Inland Seas 27:3 (September 1971), 163-173; Al Miller, Tin Stackers: The History of the Pittsburgh Steamship Company (Detroit: Wayne State University Press, 1999); Jay C. Martin, "Only the Shipyards Will Gain: The Buffalo Hurricane of 1921 as a Demonstration of the Combined Economic Power of Commercial Carriers on the Great Lakes," The Northern Mariner 25:2 (April 2015), 133-146; Brent Fisher, "Wood Ships, Iron Men, Iron Ships, Wooden Men: The Great Lakes Labor Strike of 1909" (master's thesis, Bowling Green State University, Bowling Green, Ohio, 2005).

2 James Christopher Healey, Foc's'le and Glory-hole: A Study of Merchant Seamen and His Occupation (New York: Merchant Marine Publishers Association, 1936), 25-28; Walter Lewis, "Transition from Sail to Steam on the Great Lakes in the Nineteenth Century," The Northern Mariner 15:4 (October 2015), 345-374; Martin, 194-197. 
meant that mates and even able-bodied seamen, given the necessary financial resources could all aspire to their own commands. The new steamships resembled factories on-shore with specific tasks of limited responsibility, a sharp de-skilling of deck work, and new pressure to meet schedules. It also meant that sailors faced declining wages as they could no longer claim sole possession of skills acquired by years of training and experience. ${ }^{3}$

Vessel owners had defeated many union efforts during the early 1880s and new efforts coalesced around the Knights of Labor in 1886. They had been formed in 1869 , and by 1886 were the largest labor union in the United States counting nearly 800,000 members. Unlike the craft-oriented American Federation of Labor, the Knights of Labor accepted unskilled workers into their ranks as well. This broad coalition would also prove their undoing when faced with economic unrest, internal dissent, and the hostility of state and federal government. They allowed steam sailors to join, but the lack of a broad organizing plan weakened the Knights. A group abandoned them in 1894 to form a union federated with the new International Seamen's Union. The new Lake Seamen's Union admitted sail and steam mariners, which was a contentious issue. Traditional sailors were angered by their loss of collective identity and autonomy. Worse, the union demanded that they find common cause with those viewed as the reason for their situation. This they encapsulated in the lament: "Wooden boats, iron men: iron boats, wooden men." 4

The 1890s saw further labour changes. Led by longshoreman and tugboat captain Daniel Keefe, the International Longshoreman's Association was formed from the 1877 Association of Lumber Handlers. In 1892 it became the National Longshoremen's Association of the United States. The latter was also affiliated with the conservative American Federation of Labor and became international by adding Canadian longshoremen in 1895. Keefe took far more conservative positions than other unions by asserting strict central control over locals and agreeing to contracts that had the longshoremen provide strike-breakers should locals engage in unauthorized strikes. Such actions earned it the accusation of being a mere company union that limited opportunities for workers. ${ }^{5}$

Though both unions initially avoided conflict, the jurisdiction disputes between them, the tension between steam and traditional sailors, and the growing strength of the owners would alter the balance. The longshoremen's desire to expand onto the ships by recognizing the Marine Firemen, Oilers and Watertenders Benevolent Association, an explicit rejection of the Lake Seamen's brought the two unions

3 Theodore J. Karamanski, Schooner Passage: Sailing Ships and the Lake Michigan Frontier (Detroit: Wayne State University Press, 2000), 111-116; Jay Cohen Martin, "Sailing the Freshwater Seas A Social History of Life Aboard the Commercial Sailing Vessels of the United Stated and Canada on the Great Lakes, 1815 - 1930" PhD thesis, Bowling Green State University, Bowling Green, Ohio, 1995, 181-184.

4 Journal of the Lake Seamen's Union, 20 February, 1894, quoted in Hoagland, 16.

5 Maud Russell, Men along the Shore (New York: Brussel \& Brussel, 1966), 63. 
into open warfare. ${ }^{6}$ The conflict between the longshoremen and the sailors ranges far beyond this narrative, but at its core it left a deep rift at a time when solidarity was needed most. ${ }^{7}$

\section{The Lake Carriers' Association and the New Order}

With the expansion of the bulk material trade on the Lakes and the rise of unionizing efforts after the 1860 s, vessel owners sought ways to retain control of their fleets. The modern Lake Carrier's Association grew from the April 1892 merger of the Cleveland Vessel Association of 1880 and the original Lake Carriers' formed in 1885 . The new entity had a stated purpose to improve navigational aids and sailing rules, to foster communication between owners, and to address labour issues. Though nominally reliant on the work of an executive committee of owners, in practice the large membership of independent-minded owners stymied much of their work. The greatest successes of the association came from its ability to lobby members of Congress for bills and appropriations to aid navigation. ${ }^{8}$

The 1890s depression revealed the financial instability and the extent of overbuilding across a range of industries. Fewer larger firms remained by the end of the decade. In Minnesota's Mesabi Iron Range, the Merritt family found themselves locked in a struggle with John D. Rockefeller for control of their ore empire. The Merritts were among the first to attempt having a dedicated vessel fleet to transport Mesabi and Gogebic Range iron ore, but the sheer scale of their efforts overwhelmed their financial and managerial abilities. ${ }^{9}$ Within this changed environment Rockefeller's principle lieutenants, Frederick Gates and Lamont Montgomery Bowers, created the Bessemer Steamship Company. The ore hauling fleet utilized vast amounts of data regarding fuel consumption, travel time, unloading time, and to introduce improvements to the technology of their vessels. Though captains and owners had long been concerned with expenses, this new data-driven method reflected the shift towards a highly structured transport system coupled to high volume cargoes with relatively small per trip profit based in season-long contracts. Demurrage penalties built into contracts also meant that any delay then ate into the profits pushing captains to maintain schedules, avoid delays, and to move the process along as fast as possible. ${ }^{10}$ The expansion of managerial

6 "Attempt to Form a Local Branch of the International Sailor's Union Was Spoiled by Firemen," Duluth Evening Herald (DEH), 31 March 1900.

7 For an extended discussion see Russell, Men Along the Shore, and Hyman Weintraub, Andrew Furuseth, Emancipator of the Seamen (Berkeley: University of California Press, 1959).

8 George J. Ryan, Lake Carriers' Association History (Bloomington, Indiana: Xlibris LLC, 2017), 15-17.

9 Paul De Kruif, Seven Iron Men (New York: Blue Ribbon Books, 1934); C. Roger Pellett, Whaleback Ships and the American Steel Barge Company (Detroit: Wayne State University Press, 2018), 103-117; David Allan Walker, Iron Frontier: The Discovery and Early Development of Minnesota's Three Ranges (St. Paul: Minnesota Historical Society Press, 1979), 174-178.

10 Vessel charter for Barge 115 between American Steel Barge Company and John D. Rockefeller, 15 September 1893, Rockefeller Archive Center, Sleepy Hollow, New York, Office of the Messrs. Rockefeller, RG2, Series C, Business Interests, FA312, Box 52, Folder 439; Frederick 
principles in the operation of vessels and their connection to vertically integrated companies only increased as other firms such as Andrew Carnegie's Oliver Mining Company and its Pittsburgh Steamship Company, the Hanna Mining Company, and Pickands, Mather Company also expanded rapidly. ${ }^{11}$ These house fleets drew on the resources of corporations that owned mines, steel mills, railroads, and loading facilities to go with the ships that moved their ore.

The 1901 formation of United States Steel created a giant, vertically integrated corporation that combined multiple fleets into the reorganized Pittsburgh Steamship Company, making it the largest on the Great Lakes. The vessels of these fleets took first priority for cargoes and only utilized independent fleets to make up for any shortfalls in tonnage. Some independent fleets rapidly replaced their wooden tonnage. By 1908, one of them, the Gilchrist Transportation Company of Cleveland, had the second largest collection of steel ships on the Lakes. Gilchrist Transportation, however, owned no mines, docks, mills, or railroads making it reliant on external contracts for ore, coal, and grain as markets dictated unlike house fleets that simply tied up when demand declined. This also meant that any economic downturns or labour disruptions made fleets like Gilchrist fiscally vulnerable. ${ }^{12}$

\section{The Welfare Plan}

Recognizing the difficulties unionization posed to its members, the Lake Carriers' moved to assist their members by offering an alternative system to the unions. Initially devised in 1901 as the Lake Carriers' Beneficial Association (renamed the Welfare Plan in 1907) it consisted of a series of interlocking policies designed to prevent labour organizing and provide for sailor welfare. ${ }^{13}$ The plan

T. Gates (FTG) to Lamont M. Bowers (LMB), 1 April 1896, 83; F.T.G. to L.M.B., 21 April 1896, 105; F.T.G. to John McBride, 15 July 1896, 183; F.T.G. to L.M.B., 8 February 1897, 359, all in Rockefeller Archive Center, John D. Rockefeller Papers, Bessemer Steamship Company Letterbook, RG1, Series L, Vol. 377; Data Book, 1907-1908, Pittsburgh Shipbuilding [sic] Co., microfilm, GLMS-349, McDougall-Duluth Company Records; "Final Analysis Schedule I, 1893-1905," Box 66, Folder 47: Contracts, Agreements, GLMS-21, Wilson Marine Transit Co., both from Historical Collections of the Great Lakes, Center for Archival Collections, Bowling Green State University Libraries (HCGL-BGSU).

11 "Vessel Reporting Service," Cleveland Plain Dealer (CPD), 19 February 1897; "For Reporting Vessesl [sic]," Oregonian, 4 March 1901; "Extend the Wireless," CPD, 18 June 1904; "Owners of Boats Favor the Plan," Duluth News-Tribune (DNT), 24 October 1905; "Marine Work," Annual Report of the Department of Agriculture, 1912 (Washington, DC:Government Printing Office, 1913), 40-41.

12 "Building Steamers Upon Bonds," The Marine Review 18:11 (10 September 1903), 23; "Navigation News," Bay City Times (BCT), 17 June 1908; Jerome K. Laurent, "Trade Associations and Competition in Great Lakes Shipping: The Pre-World War I Years," International Journal of Maritime History 4:2 (December 1992): 117-153; Laurent, “'And Cut Throat Competition Prevented:' Concentration and Control in Great Lakes Transportation, 1915-1940," International Journal of Maritime History 14:2 (December 2002), 43-84; Alexander C. Meakin, The Story of the Great Lakes Towing Co. (Vermilion, OH: Great Lakes Historical Society, 1984), 16, 22; Miller, 51-54.

13 "Members Will Vote On It," CPD, 17, February 1901; "Insurance for Lake Sailors," 


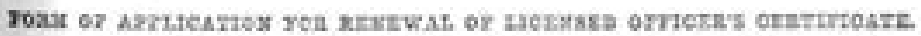

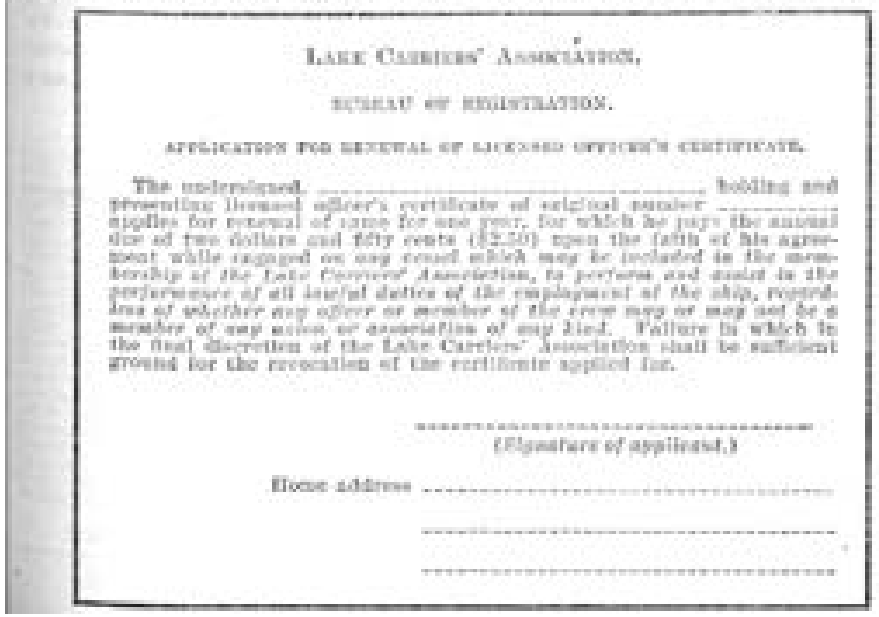

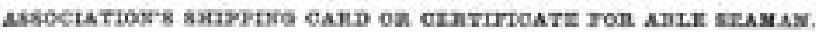

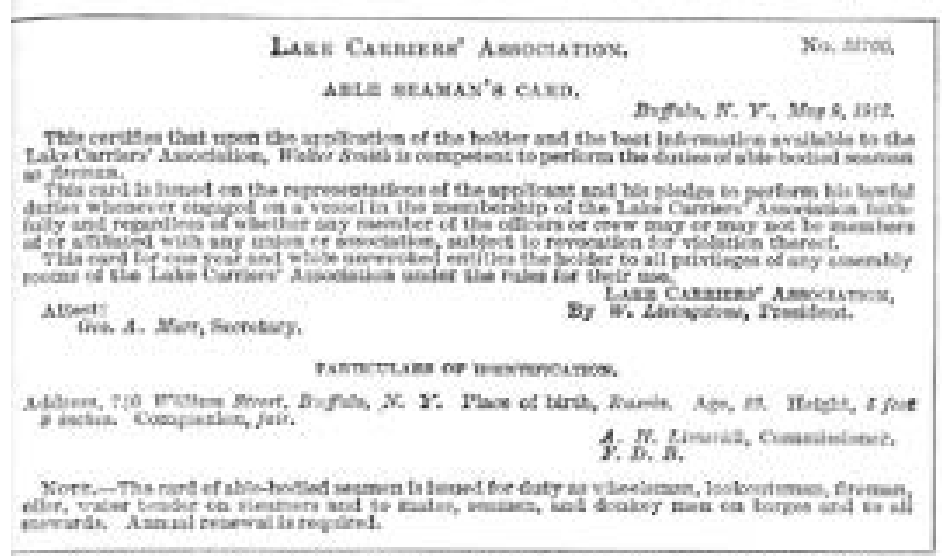

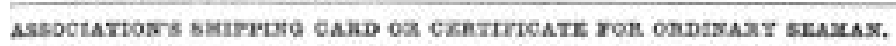

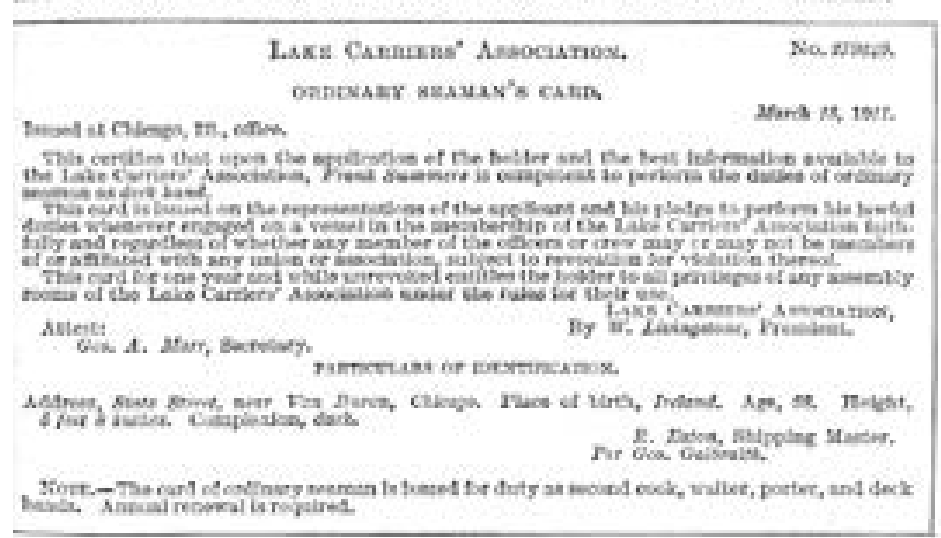

From the report "Employment System of the Lake Carriers' Association" by Paul F. Brissenden (Washington, D.C.: Government Printing Office, 1918) 
operated under the direction of the executive committee of the Lake Carriers' with day-to-day operations handled by the secretary. Individual vessel captains remained in command of the ship's operations, but the new system required that they conform to the policy. ${ }^{14}$ The Welfare Plan created a system of assembly rooms throughout the major Great Lakes ports overseen by a regional commissioner. These rooms offered amenities such as libraries and other facilities intended to take the place of union hiring halls and served as central locations where captains placed requests for crewmen..$^{15}$

Admission to the program demanded seamen and officers to disavow any union affiliation and to pledge loyalty to owners. Qualification certificates were "revocable in the discretion of the association" should the bearer be accused of union activity. ${ }^{16}$ Obtaining the certificates of competency such as for able-bodied seaman or for holders of government licenses for officers required the affirmative recommendation of another officer. Again, the certificate stipulated that the seaman or officer "will faithfully perform all lawful duties without reference to membership or affiliation...in any union or association whatsoever." ${ }^{17}$ It then remained to create a system to monitor and enforce participation.

The records of sailors and officers below the captain and chief engineer were documented in record discharge books, which upon discharge would receive an entry of "good" or "fair" from the appropriate officer. A negative evaluation would result in the revoking of the discharge book. Justified as an incentive for promotion and a continuous credential, it served as a powerful tool for vessel owners to manage their workforce.

The assembly rooms facilitated employment but captains could still reject those men sent to them and request a different officer or seaman. ${ }^{18}$ However, the captain and chief engineer could not go outside the system to find sailors unless those men had registered for a discharge book. The captain then created a crew list for each trip to send on to the home office for tracking purposes. While the system did not micro manage captains, it placed them within a corporate bureaucratic system with clear lines of reporting and authority.

The final component of the Welfare Plan covered members' injuries or death.

Detroit Evening News, 28 February 1901; "Hours of Labor of Lake Seamen," Marine Review 15:11 (13 March 1902), 15; Stuart Brandes, American Welfare Capitalism, 1880-1940 (Chicago: University of Chicago Press, 1976), 9, 32-33; Daniel Nelson and Stuart Campbell, "Taylorism Versus Welfare Work in American Industry: H.L. Gantt and the Bancrofts," Business History Review 46:1 (Spring 1972), 2-3; Ryan, 102-9.

14 Hoagland, 92-93; Captain Herbert W. Dosey, "The International Ship Masters Association," Inland Seas, 33:4 (December 1977): 272-276; Jay C. Martin, "The Principle of Beneficence: The Early History of the International Ship Masters Association," Hayes Historical Journal 11:1 (no month, 1991): 29-41.

15 Ryan, 109-12.

16 George A. Marr, "Welfare Work of the Lake Carriers' Association," Monthly Bulletin of the American Iron and Steel Institute 3:6 (1915), 159.

17 Ibid.

18 Ibid., 163. 
Unlike land-based programs that attempted to offer more expensive long-term pension plans, the association avoided such policies, favouring instead a schedule of one-time payments in case of shipwreck, accident, or disabling injury. ${ }^{19}$ The program improved on its land-based counterparts such as Henry Ford's "Five Dollar Day" by spreading the costs across a cohesive membership of vessel owners, with the association administering the program instead of individual fleets, thus helping to build unity.

\section{Strikes, Fragmentation, and Solidarity}

Great Lakes shipping, as in other industrial sectors, faced a growing tide of worker unrest at the turn of the twentieth century. Despite the conflict between the seamen's union and the longshoremen, efforts to organize vessel fleets intensified. Between 1901 and 1908 three major strikes by unions took place against the Lake Carriers' Association and its member fleets. Yet, these strikes deepened divisions between unions, between categories of sailors, and weaken the unionization effort as a whole. Pressed to find new answers, the owners adopted new measures and stronger leadership to resist labour's efforts. Coupled with a sharp economic downturn, the actions of unions and owners set the stage for the 1909 strike and its outcome.

The first of these strikes began in January 1901 coinciding with the announcement by owners of the initial Beneficial Plan. The engineers of the Marine Engineers Beneficial Association demanded greater staffing for steamers and greater definition of skill levels on ships. ${ }^{20}$ The owners refused to negotiate, stating that to do so would give the engineers de facto recognition. That they would not do. Independent from both the sailors or the longshoremen, the engineers received nor requested assistance from neither union. ${ }^{21}$ Targeting the vulnerable passenger and package freight companies that could not afford a strike, the Lake Carriers' relented by mid-May and permitted individual companies to negotiate..$^{22}$ Though ostensibly a victory for labour, it presented no official recognition by owners, nor did it foster inter-union cooperation. The owners withdrew the Beneficial Plan and debated how to create greater unity.

The second strike against the Lake Carriers' Association came from

19 Marr, 160. For discussions of land-based plans see Colin Gordon, New Deals: Business, Labor, and Politics in America, 1920-1935 (New York: Cambridge University Press, 1994), 245; Brandes, 105-106.

20 "He Will Get Better Wages," CPD, 23 January 1901; "Engineers Are Ordered Out," CPD, 24 January 1901.

21 "Engineers Stand Pat," DNT, 1 March 1901; "Left for Erie," CPD, 7 March 1901; "They Will Keep Their Hands Off," CPD, 10 March 1901; "Longshoremen Cannot Strike" MC, 11 March 1901.

22 "Stopped Work on the Vessels," CPD, 1 March 1901; "Striking Engineers are Firm," $C P D$, 2 March 1901; "Engineers' Strike Notes," Muskegon Chronicle (MC), 9 March 1901; "Talk With Owners," DNT, 25 April 1901: "Men Will Start to Work," CPD, 27 April 1901; "Engineers Go To Work," DNT, 14 May 1901; "To Unionize Lake Labor," The Marine Record 24:20 (14 November 1901), 15. 
dissatisfaction of licensed deck officers such as captains, mates, and pilots and came in two parts during 1903 and 1904. Officers' roles faced disruption by the same forces affecting seamen and vessel operators. They had joined the American Association of Masters and Pilots. Like the engineers in 1901, the officers stood apart from the other unions. ${ }^{23}$ Though a brief work stoppage had taken place in March 1903 the conflict regarding the captain's authority and the hiring and promotion of sailors resulted in a new strike on 1 September. ${ }^{24}$ By the end of the month the Lake Carriers' and the officers agreed to mediation during the winter. ${ }^{25}$ However, the off-season brought the Pittsburgh Steamship Company's Harry Coulby, a labour hardliner, to the leadership of the association along with new articles of association. These articles vested additional power to the directors and transformed the Lake Carriers' into a "super" trade association capable of applying policy and the ability to discipline wayward members. By agreeing to these articles, owners accepted a voluntary alliance. Not being an alliance member meant being left to union dictates. ${ }^{26}$

During the winter of 1904, Coulby argued that captains served as direct agents of owners and should not take any action that would be against their interests or answer to any organization outside of the company. ${ }^{27}$ The weak economic climate and disaffection of older captains undermined the officers' union. Though a strike began on 1 May 1904, scores of captains, mates, and pilots crossed picket lines and accepted appointments. By 16 June, the strike collapsed and ended officers' efforts to challenge the owners. ${ }^{28}$ Again, the Lake Seamen's Union and the longshoremen

23 "Masters May Form a Union," CPD, 22 January 1901; "Plans About Completed," CPD, 28 January 1903; "Will Tie up the Lake Fleet," CPD, 25 March 1903.

24 "Lake Carriers Make a Stand," CPD, 28 March 1903; "Sailors' Strike Comes to an End," DNT, 29 March 1903; "They Reached a Deal," CPD, 29 March 1903.

25 "More Trouble is Brewing," MC, 29 May 1903; "Association May Help Out Loftus," DNT, 31 May 1903; "Trouble on the Lakes," SSMEN, 1 June 1903; "More Power for the Masters," CPD, 18 August 1903; "He is Not a Member," CPD 9 September 1903; "Warfare Waged on Capt. Rae," DNT, 15 September 1903; "Looks Like a Finish Fight," CPD, 16 September 1903; "Steel Corporation Vessels Going to Dock," Marine Review and Marine Record (MRMR) 27:12 (17 September 1903), 22; "Trouble with Mates and Masters," MRMR 28:13 (24 September 1903), 22; "Strikers Gain More Converts," DNT, 18 September 1903; "Will Operate Consorts," CPD, 20 September 1903; "May Make Shift in Their Plans," CPD 23 September 1903; "Lake Strike Is Settled and All Men Will Return to Their Boats," DNT, 26 September 1903; "All Hands On Deck Again," CPD, 26 September 1903; "The Lake Captain - Organized Labor," MRMR 28:14 (1 October 1903), 17-18; "Lake Labor Problem," MRMR 28:28 (12 November 1903), 22.

26 Joseph F. Bradley, The Role of Trade Associations and Professional Business Societies in America (University Park: Pennsylvania Sate University Press, 1965), most importantly "Chapter 3: Organizational Aspects of Associations."; Hoagland, 92-93; "Shipwrecks on the Great Lakes and the Lake Carriers' Association," Retrieved through the University Library of Munich, Germany in its series MPRA Paper 11378, http://ideas.repec.org/p/pra/mprapa/11378.html (accessed May 15, 2018); Fisher, 42-43; Hoagland, 42; Miller, 87-93.

27 Annual Report of the Lake Carriers' Association (Cleveland: Lake Carriers' Association,1903), 4-7.

28 "When Will Spring Navigation Open," Saginaw News (SN), 15 February 1904; "Want Their Old Places," CPD, 19 February 1904; "Boats Will Buy Supplies Here," DNT, 19 March 1904; 
had stood aside and allowed the Lake Carriers' to obtain a real victory this time not just over the officers but also for their ability to maintain unity contrary to the 1901 strike.

The third and final strike delivered a gift to the Lake Carriers' when the longshoremen's union attempted to move against the Lake Seamen's Union. During the winter of 1906, the longshoremen attempted to organize the officers again, and called a strike for 1 May. ${ }^{29}$ The sailors' union cut a deal with the owners to remain out of the conflict, leaving the longshoremen on their own. The strike effort did not mmediately go as hoped. Instead of mates flocking to the new union, they remained on duty. Pressure from members caused union leadership to call the strike off by 13 May. ${ }^{30}$ The defeat brought new leadership and a more limited view of the union's goals but did not end the conflict with the sailors. ${ }^{31}$ For the vessel owners, the internal union strike enhanced their own actions providing an even greater victory.

The Lake Carriers' Association, having successfully defeated one of its two major union adversaries, took advantage of the October 1907 financial panic to exert its new strength. Predicting a major drop in ore shipments, the owners at a special meeting on 9 April 1908 moved to terminate any existing contracts, adopt the open shop, and reimplement the Beneficial Plan, now renamed the Welfare Plan. The association's abrupt policy shift to the open shop caught the unions offguard. Coupled with limited employment opportunities even on shore, the Lake Seamen's Union pushed its members to sign-up for berths before non-union sailors replaced them, promising retaliation the next season. ${ }^{32}$ Other factions argued that any strike would fail, and would make the open shop a permanent reality. ${ }^{33}$

\footnotetext{
"Not Pleased with the Work," CPD, 16 March 1904; "More Contracts Are Sent Out," CPD, 16 May 1904; "First Break in Lake Strike Occurs," DNT, 5 June 1904; "Mate Chased by an Angry Mob," CPD, 6 June 1904; "Mob Stones Boat in Buffalo Canal," DNT, 11 June 1904; "Lake Captains Admit Defeat," DNT, 15 June 1904; "Fate of the Ship Master's [sic] Association," Marine Record (MR) 30:4 (28 July 1904), 21-22.

29 "Keefe Urges Mates to Stand Together," Cleveland Leader (CL), 24 January 1906; "Will Not Meet With the Mates," CPD, 26 January 1906; "Owners Say Labor Men Are Bluffing," $C L, 24$ March 1906.

30 "Lake Strike is Probable," CPD, 16 March 1906; "Seamen Yield to the Lake Carriers," $C L$, 27 March 1906; "To Stop Work at Midnight," CPD, 30 April 1906; "Fight Will Be Long and Hard," $C P D, 1$ May 1906; "The Great Lakes Strike," $S N, 3$ May 1906; "Keefe Goes to Cleveland," SN, 8 May 1906; "Longshoremen Back at Work," Sault Ste. Marie Evening News (SSMEN), 10 May 1906; "Marine Strike At End; Mates Union Breaks to Pieces," CL, 10 May 1906; Marine Firemen, Oilers, and Water Tenders Benevolent Association (MFOWBA) Meeting Minutes, Superior, Wisconsin, 5 April 1906, Box 1, Folder: Minutes of Meetings, 1905-1906; MFOWBA Meeting Minutes, Buffalo, 1 May 1906, Coll. 01308, Box 1, Folder: Minutes of Meetings, 1906-1906, International Seamen's Union of America Records,1899 -1940, Burton Historical Collection, Detroit Public Library (ISUDPL).

31 MFOWBA Meeting Minutes, Buffalo, 24 April 1906, Box 1, Folder: Minutes of Meetings, 1905-1906, ISU-DPL.

32 Edward Stack Statement, Buffalo Local Meeting Minutes, 18 May 1908, Box 1, Folder "Correspondence, 1908," ISU-DPL.

33 Michael Casey to Robert Clarke, 27 June 1908, Box 1, Folder: Correspondence; and John
} 
The amount of cargo shipped on the Great Lakes during 1908 had plunged by more than half from 1907 totals. Iron ore, the largest total commodity hauled, saw its tonnage drop from $40,727,972$ to $24,939,185$ gross tons in 1908 , a 40 percent decline by the close of navigation. ${ }^{34}$ Even so, the reduced amount was an estimated 20 percent greater amount than demand required. Companies built up stockpiles ahead of anticipated labour trouble. Making the most of their position, the owners announced unilateral wage freezes and the continuation of the open shop. ${ }^{35}$

\section{The Strike of 1909}

Despite the promise to move toward strike action on 1 May the sailor unions stood on unstable ground during the winter of 1908-09. Though they had previously stood apart from the Marine Engineers Beneficial Association, and the Marine Firemen, Oilers and Water Tenders Benevolent Association, the Lake Seamen's Union nowchose to work with them. Leaders confronted their limited ability to provide financial support to striking workers. ${ }^{36}$ Without this backing, unity within the various unions would have been difficult to achieve. Though the engineer's union had rejected the open shop and yellow-dog contracts even for licensed sailors in June 1908, a number of engineers left in January 1909 to accept positions after facing bleak work prospects on shore. ${ }^{37}$ The defections gave the Lake Carriers' the opportunity to claim that their vessels had all the engineers they needed. Despite this unsettling turn of events sailor affiliated unions still pushed ahead with the strike..$^{38}$ On 1 May 1909 the Lake Seamen's Union and its remaining union allies declared a strike effective..$^{39}$

The Lake Carriers' immediately implemented the contingency plans they had prepared since 1903. Tall slab fences already under construction were rushed to completion, limiting access to critical dock facilities. Private security and detective

Fisher to Robert Clarke, 20 November 1908, Box 1, Folder: Correspondence, 1908, ISU-BHC-DPL; "Union Lake Men in Predicament," CL, 27 July 1908; "Lake Seamen's Union Dislikes 'Welfare Plan," DNT, 17 December 1908; "Marine Men Against Strikes," Toledo Blade (TB), 17 December 1908.

34 "Movement of Ore is Reduced 50 Percent," Detroit Free Press (DFP), 4 September 1908; "Coal Shipments Fall off Badly," DEH, 27 October 1908; "Total Ore Shipments," Duluth Evening Herald (DEH), 15 December 1908; "Domestic Commerce on the Great Lakes," Annual Report of the Department of Commerce and Labor, Internal Commerce of the United States, (Washington, D.C.: Government Printing Office, 1909), 1095-1097.

35 Annual Report of the Lake Carriers' Association (Cleveland: Lake Carriers' Association, 1908), 10

36 MFOWBA Meeting Minutes, Buffalo, New York, Box 1, Folder: Superior, WI-Meeting Minutes, 1908-1909, ISU-BHC-DPL; “Annual Meeting of the Lake Carriers' Association," MR, 39, No.3, (21 January 1909), 22; Larrowe, 36-38.

37 "Engineers Won't Sign," DFP, 5 June 1909.

38 "Lake Carriers for Open Shop," DNT, 21 January 1909; "More Engineers to Sign Contracts," DFP, 28 January 1909; "All the Engineers that He Needs," DEH, 12 March 1909; "Engineers are Signed," $D E H, 5$ April 1909; "Livingstone to Ignore Unions," DNT, 16 April 1909; "Expect Strike at all Ports," TB, 21 April 1909.

39 “15,000 Seamen on Lakes on Strike,” DFP, 1 May 1909. 


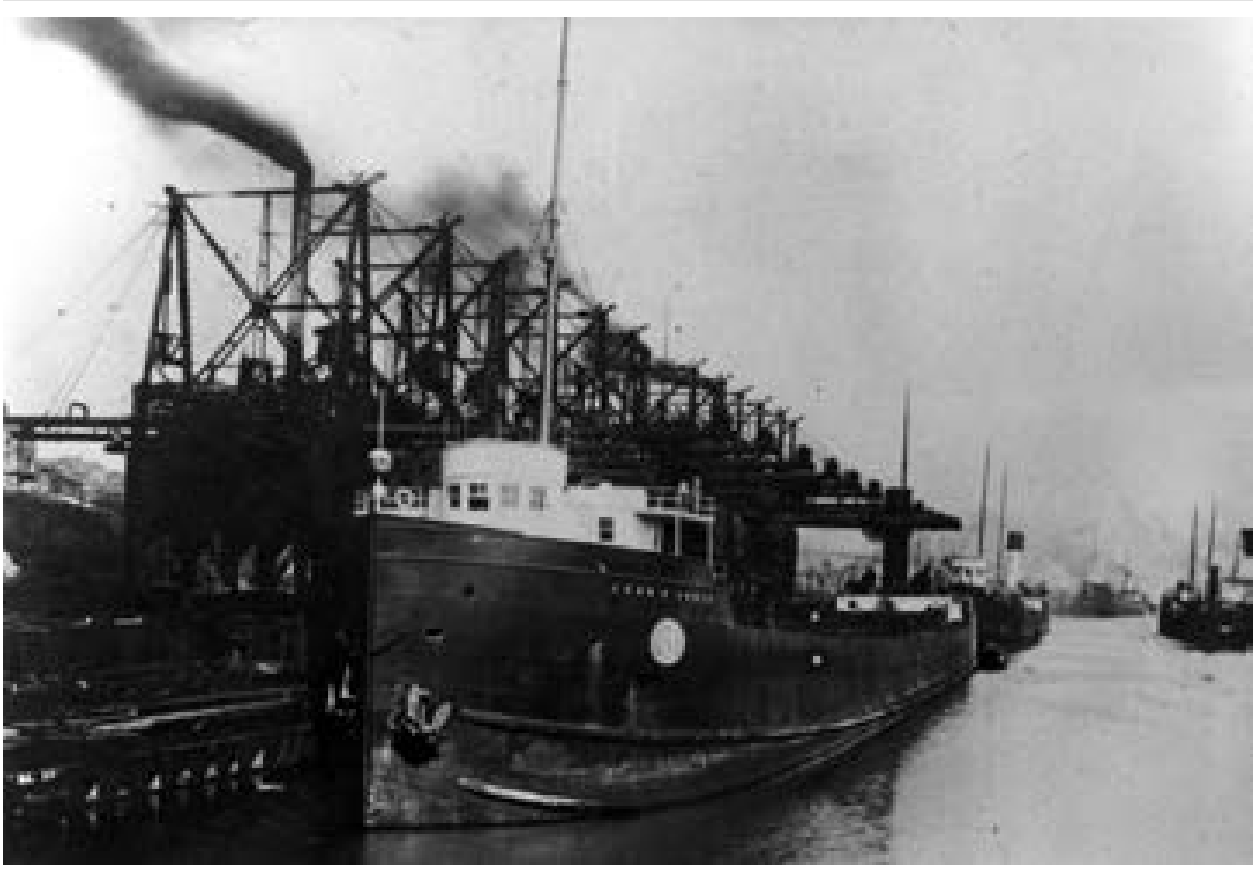

John B. Cowle (built 1902) seen here unloading coal, collided on July 12, 1909 with the brand-new Isaac M. Scott. (Thunder Bay Research Collection, Alpena County Public Library)

agencies took up positions to protect those willing to cross the picket lines and to hassle strikers. The association again recruited sailors from the East Coast as they had in 1901 to get their fleets up and running. ${ }^{40}$

From the start of the strike, both sides utilized the media as a tool to shape public opinion and to bolster their positions. Though the Lake Seamen's Union had access to an affiliated publication, The Coast Seamen's Journal, the sailors received limited attention. Union leaders relied on newspapers both to spread their message and for news of the strike. Though often hostile, union leaders noted that a number of marine reporters and editors were sympathetic to the strikers and carried favourable stories and press releases with few alterations.$^{41}$ Among the most serious lines of attack by the sailors was the charge that the owners had resorted to using underage boys as sailors, inexperienced men as engineers, and other violations of their stated policies. ${ }^{42}$ The Lake Carriers' countered stating: "Everything is lovely. None of our men are quitting worth mentioning, and when one does we are able to find three to take his place provided we needed them. [sic]."43 They further asserted strict adherence to policy and prohibited the hiring of inexperienced men or family

40 "Guards are Employed," DEH, 1 May 1909.

41 Michael Casey to Robert Clarke, 27 June 1908, Box 1, Folder: 1908, Correspondence, ISU-DPL.

42 Michael Casey to Robert Clarke, 1 July 1909, Box 2, Folder: MFOWBA, 1909; Joseph Liebold to Robert Clarke, 23 May 1909, Box 2, Folder: MFOWBA, 1909, ISU-DPL.

43 "Report Sailors Leave Vessel," DNT, 7 May 1909. 
members. Incidents in 1909 would challenge those claims.

A month into the strike the Soo Locks experienced one of the most serious accidents in its history. On 9 June, the passenger ship Assiniboia and the PSC freighter Crescent City were downbound through the Canadian lock. The Gilchrist freighter Perry G. Walker, upbound, approached the lower gates in preparation to lock through. Confused signals between the pilothouse and the engine room resulted in the Walker ramming the lower gates at full speed. The collision caused the sudden emptying of the lock, with the still open upper gates being torn away. The two vessels inside were swept out with the full weight of Lake Superior driving them. Both vessels struck the Walker, but the Crescent City received the most damage, sinking later at a dock. The Canadian lock was closed for twelve days later. The Lake Seamen drew attention to the competence of the strike-breakers in the handling of the Lake Carriers' vessel. The LCA dismissed the incident as an accident and deflected the discussion to the need for an additional lock to handle traffic. ${ }^{44}$ November brought a second collision with lock gates, this time on the US side's Poe Lock by the freighter Isaac M. Ellwood. Fortunately, the closed lower gates prevented a repeat of June's outcome. Once again miscommunication was blamed, and the accident snarled traffic for days. ${ }^{45}$

On Monday, 12 July 1909 near Whitefish Point on Lake Superior the 420-foot steel freighter John B. Cowle, downbound with ore from Two Harbors collided the brand-new, 504-foot Isaac M. Scott. Catastrophic flooding trapped some of the Cowle crew within the hull while others jumped into the lake without even the time to grab life preservers. ${ }^{46}$ The Cowle's sinking ten weeks into the strike opens a window to crew composition and experience during the strike. It carried a large number of crew from the same community as the captain, Watertown, New York. A similarly large percentage of the crew had recently become sailors or were foreign born but without experience. Both the captain and the chief engineer had their teenage sons working with them. Experience also played a role in the Cowle's loss as the wheelsman on duty was new to sailing and had only a few weeks experience. The vessel association's leadership had pushed companies to end the practice of hiring family members in 1904 yet the Cowle had multiple members on board. This coupled with the high percentage of new sailors with critical roles and little experience indicates possible issues manning the vessels, the non-enforcement of association policies, or a command to crew the ships at any cost. Despite their

44 "Escape of Boats was Miraculous," and "The Accident to the Canal," SSMEN, 10 June 1909; "Gates Swept Away," Buffalo Evening News, 10 June 1909; “Accident at Sault Ste. Marie," MR, 39 (July 1909), 186-189.

45 "Steamer Ellwood Wrecks Soo Gate," CL, 11 November 1909; "Wrecked Gate of Lock at Zoo [sic]," CPD, 11 November 1909; "Gate of Poe Lock at Soo Wrecked," SSMEN, 10 November 1909.

46 "Cost Lives of Fourteen Men," Bay City Times (BCT), 13 July 1909; "14 Perish with Cleveland Boat," CPD, 13 July 1909; "Captain Rogers Reaches Duluth,” DNT, 14 July 1909; Frederick Stonehouse, Lake Superior's Shipwreck Coast: Maritime Accidents from Whitefish Bay to Grand Marais, Michigan (Au Train, Michigan, 1985), 142-45. 
rhetoric, the imperatives of winning the strike had clearly impacted the Lake Carriers' policy. ${ }^{47}$

Though denied by the association, the trade publication Marine Review recorded a startling surge for 1909 and 1910 in strandings, groundings, and collisions compared to previous years. For example, collisions leaped from 59 in 1908 to 125 in 1909, a massive increase and reflective of the strike's impact during an era when such incidents since 1905 had followed a long-term decline. It is also worth noting that these were events worthy of reporting and do not include minor harbour accidents during unloading and docking. While storms like November 1913 receive the greatest attention for their loss of life, incidents such as these reflect the hazards of routine operations and the need for experience. ${ }^{48}$

Concerned by the sheer size of the strike, state arbitration boards of New York, Ohio, Indiana, Illinois, Wisconsin, and Michigan offered to mediate and the seamen's union moved quickly to announce their willingness to negotiate. ${ }^{49}$ Lake Carriers' president William Livingstone in reply to the board stated: "As we are defending a fundamental principle which does not permit arbitration we must decline to attend." ${ }^{50}$ The arbitration boards appealed to the National Civic Federation to see if they could achieve a breakthrough. The Lake Carriers' Association brushed aside the overture with Livingstone stating even more unequivocally: "I have no intention whatever of answering the letter of the seamen's union asking for a conference...The letter was not written in good faith and its senders expect no answer." As to the statement issued by the unions, Livingstone dismissed them as a "tissue of misstatements" unworthy of his response. ${ }^{51}$ A few owners came to the meeting, but to no result.

As the strike continued, the recurrent problem of labour solidarity further eroded the strikers' resolve. The longshoremen's new leader, T.V. O'Connor, had replaced Daniel Keefe but continued his pro-business policies. ${ }^{52}$ Throughout the winter O'Connor's union had watched the Lake Carriers' preparations for a sustained conflict. While the longshoremen understood that the strike would

47 “Cannot Hire Relatives," CPD, 26 February 1904; "Report Sailors Leave Vessel,"DNT, 7 May 1909; "Fourteen Men Drown When Ship Goes to Bottom in Lake Superior,"DNT, 13 July 1909; "14 Lose Lives in Sinking of Boat Near Soo," Saginaw News, 13 July 1909; "The Great Lakes Dispute," Special Bulletins State of New York Department of Labor Vol.II “1909," Nos. 40-42 (Albany, State of New York, 1910), 132-158.

48 "Much Time Lost By Collisions," CPD, 5 February 1907; "Boiler Explosion on Steamer Hoyt," MR 38:15 (June 1909), 161-163; "Two Boats Damaged," CSJ, XXIII, No.44 (20 July 1910), 9; Annual Report of the Supervising Inspector General to the Secretary of Commerce, 1910-1911 (Washington, DC: Government Printing Office, 1911), 244-245; “Accidents Reported During Sailing Seasons," MR 46:3 (March 1916), 92.

49 Lake District Grievance Committee, ISU to Joint Board of Mediation and Arbitration, 18 May 1909, Box 2, Folder: Minutes of Meeting / Receipts and Disbursements, 1908-1909, ISU-DPL.

50 "Board Will Not Meet Again," DEH, 17 May 1909.

51 "Strike Will Continue on the Great Lakes," Marquette Daily Mining Journal (MDMJ), 2 June 1909; "The Great Lakes Dispute," Special Bulletins State of New York Department of Labor, Vol.II "1909," Nos. 40-42 (Albany, 1910), 132-158.

52 "Casey to Clarke, 11 May 1909, Box 2, Folder: MFOWBA, 1909, ISU-DPL; Larrowe, 38. 
threaten their position, they did not wish to break openly with the association.

As in many other strikes of the era, companies employed private detective agencies to hire sympathetic workers or plant operatives to inform on their workforce. One such operative within the Lake Carriers' affiliated Ohio \& Western Pennsylvania Dock Company's Cleveland division reported a fellow worker's view:

McNeff said, "other years except last year this dock would be half clean by this time, now they have enough ore here packed up to last for two years and for only one thing...both sides are so stubborn neither will give in and it is a well known fact if the engineers put up a fight all the other Marine unions would stand by them...that is why enough ore for two years use lays on these docks...I hope the unions get the best of the deal...it is not the unions, to hell with the unions, but it is the damn fools signing contracts." ${ }^{53}$

The operative also delivered the view of King Patton, a bar owner and former longshoreman on the strike and union interactions: "the lake unions are so jealous of one another that instead of helping each other they do nothing but buck each other and nothing will be accomplished by this, as it will only amount to a fight themselves." ${ }^{54}$ Absent a pan-union council, sailors and their allies lacked the collective leadership to direct a strike. The conflict-averse American Federation of Labor also provided little guidance, and O'Connor had to contend with the federation's oversight as they remained wary of the longshoremen's prior actions. Despite this a number of union locals pressed the leadership whether they should join with the striking sailors. O'Connor took a passive public stance and gave permission to a number of local branches to hold such a vote. ${ }^{55}$

Even with the rhetorical heat of the pro-strike faction, it masked the deep ambivalence held by the longshoremen as a whole. Fifty-two locals voted for a strike action, but another thirty-three voted against. For the former, some had little connection to the issues causing the strike, while many in the latter group already had contractual agreements with owners. According to the dock company operative, many workers feared to speak of organizing, were anti-union, or in the economic climate simply needed a job. ${ }^{56}$ Some locals had fewer than ten members and had little leverage. A different operative,\#21, at Ashtabula reported workers as saying: "to hell with them [unions]," and that they had recently secured a contract for work all summer. ${ }^{57}$ Other locals having unwittingly helped in the strength of the vessel owners' position, stalled the vote in order to avoid a fight they felt sure to lose. Operative \#21 also showed O'Connor's more direct role. At a longshoreman

53 Operative Report, 6 March 1909, Ohio \& Western Pennsylvania Dock Company, GLMS22, Box 4, OWPDC- BGSU.

54 Operative Report, 12 March 1909, Box 4, OWPDC-BGSU.

55 Russell, 75-79.

56 Operative Report, 6 May 1909, Box 4, OWPDC-BGSU.

57 Operative Report, 3 April 1909, Box 4, OWPDC-BGSU. 
meeting on 7 June, \#21 listened to the reading of a letter by the union chief urging them to not strike. The 15 June announcement that the union would not strike in solidarity further undermined the sailors' strike..$^{58}$

The Lake Carriers' Livingstone proclaimed on 19 June that the association's members had 280 boats in commission, or slightly more than half of their overall tonnage, with the ability to bring more on-line..$^{59}$ Though perhaps done for effect, it demonstrated the unified presence and confidence of the vessel owners. It also reflected the weak demand for cargo that further aided the association since many ships would have been laid up anyway. As a further tactic, the association utilized friendly local authorities to exert additional pressure on the strikers. Michael Casey, secretary of the water tenders union reported that in Buffalo:

A seaman was arrested here yesterday. They pulled several saloons, about 100 in all. They appointed a committee of labour men last night to see the Mayor and Police commissioners today. Olander is here and him and Stack employed a Lawyer to defend them. There is someone behind this move to get our members a little discouraged and it should make them more determined, up to this writing a lot of them got discharged and they are getting desperate trying to scare the men out on strike. ${ }^{60}$

This combination of forces arrayed against them by the economy, the vessel owners, the media, local officials, and their fellow union members applied almost overwhelming pressure.

As the strike continued through the summer, the lack of funds and shrinking memberships meant that union locals lost the leases to their social halls and became increasingly desperate from the lack of work. A Cleveland dock operative reported the growing problem outside of a saloon run by a former longshoreman fired for his union sympathies that had become the new base for union men. ${ }^{61}$ When three non-union sailors quit a boat and arrived at the saloon they received liquor and once intoxicated were ambushed outside the establishment. Enraged these men gathered other men and formed picket lines along the dock the following day and began to berate the longshoremen. ${ }^{62}$ Such incidents reflected the growing tensions between strikers and those who had opted to accept employment, and reports of fighting grew more common in the Ohio \& Western Pennsylvania Dock Company's reports.

Locals also served as enforcers of solidarity. The dock company's spy network reported that a local, having heard of a strikebreaking engineer, sought to learn the name. They sent the daughter of a member to peddle small items on board the

58 Operative Reports, 8 June 1909, Box 4, OWPDC-BGSU; “Longshoremen Will Not Strike," TB, 16 June 1909; Russell, 79-80.

59 "Lake Situation,” TB, 15 June 1909; “All the Men They Can Use,” DEH, 19 June 1909.

60 Michael Casey to Robert Clarke, 9 July 1909, Box 2, Folder: Correspondence, 1909, ISUDPL.

61 Operative Report, 21 May 1909, Box 4, OWPDC-BGSU.

62 Operative Report, 12 June 1909, Box 4, OWPDC-BGSU. 


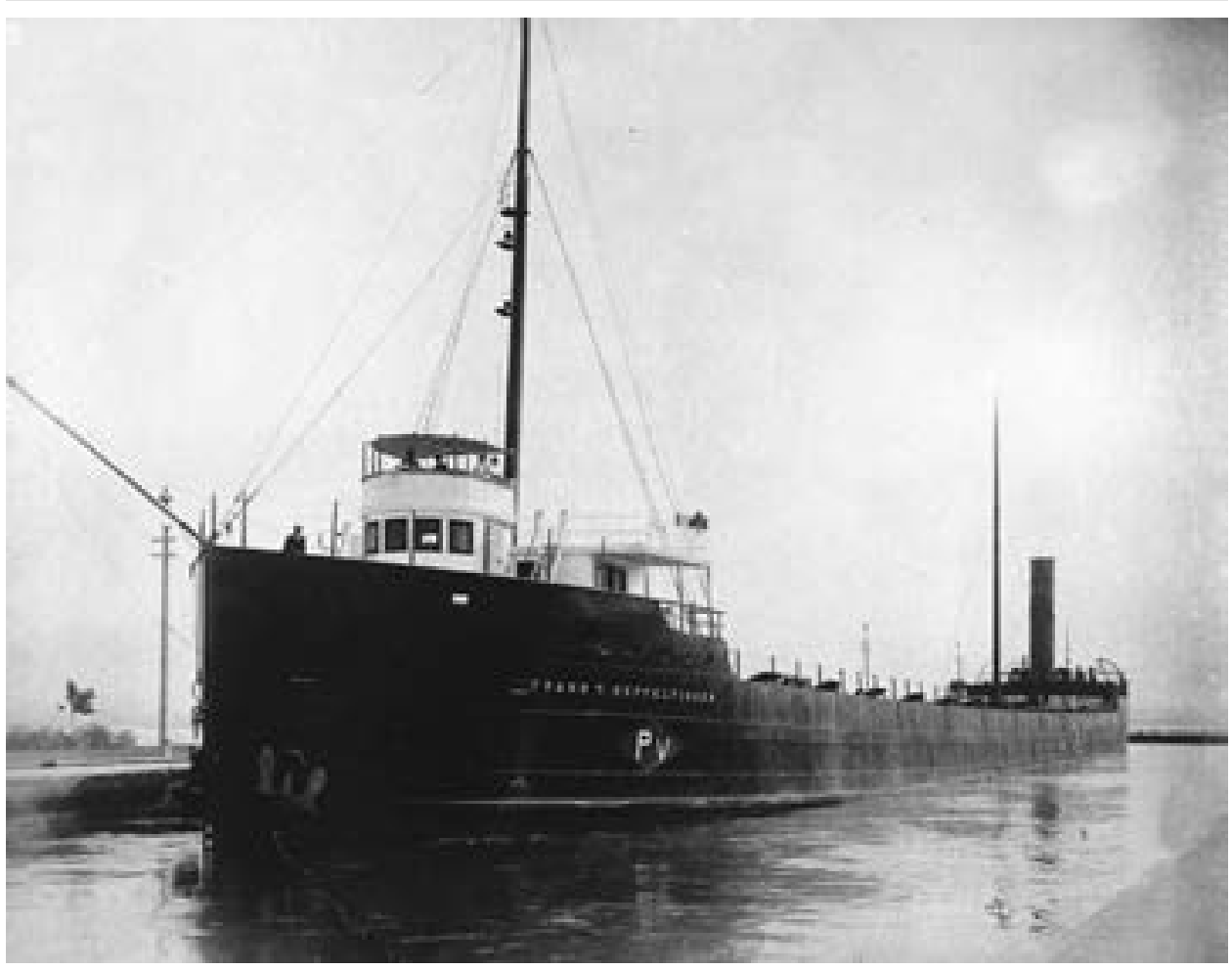

The 1902 built Frank T. Heffelfinger, sailing as a grain carrier for the Peavey Company, escaped a possible sabotage attack during the 1909 strike. (Thunder Bay Research Collection, Alpena County Public Library)

suspected ship to find out the engineer's name. They duly passed along the identity to the appropriate local who then hunted down the offender for interrogation and punishment. $^{63}$

Violence on both sides featured heavily in the strike despite pleas by union leadership to maintain the public's support. ${ }^{64}$ Assaults, robberies, and brawls along picket lines began when the strike started. Strikers threw stones at boats crewed by strike-breakers, private security killed union men in Superior and Cleveland, and clashes happened as non-union men were brought to the docks. Among the most violent of encounters came in Detroit on 19 July as the chief engineer of a non-union ship shot two union men who were threatening him. Authorities quickly accepted his claim of self-defence and exonerated him of liability ${ }^{65}$

A dock company operative reported that sailors now considered even more extreme measures to prevent scabs: "I spoke to a bunch of firemen at the Main Street Bridge, I asked them how it was coming and they said...they will fix the scabs even if they had to put dynamite in the bunkers, it might [do] well to pay

63 Operative Report, 21 May 1909, Box 4, OWPDC-BGSU.

64 Edward Stack statement, 4 May 1909, Box 2, Folder: MFOWBA, 1909, ISU-DPL.

65 "Kill Two Union Men," DFP, 18 July 1909. 
some attention to it. ${ }^{966}$ One reported incident gives credence to this report. On 26 May the Peavey Steamship Company freighter Frank T. Hefflefinger arrived in Buffalo Harbor with a grain cargo and a crew of non-union sailors. While loading a cargo of coal for the return trip, the crew discovered four sticks of dynamite stuffed into the discharge pipe of the ballast pump. Though the fuse had gone out, the location indicated a knowledge of where such sabotage would cause maximum damage. R.M. Mulfor, Peavey's Buffalo marine insurance broker, added that even with a criminal investigation an explosion would have likely been ruled the result of defective boilers, and not deliberate sabotage.$^{67}$ These actions demonstrated the tenuousness of union leadership's ability to control the strike and a growing level of internal fragmentation.

As a further sign of the disintegration of solidarity, racial and nativist ethnic discrimination, though prevalent before the strike now intensified. The Cleveland dock operative noted that among striking firemen animus towards AfricanAmericans had grown: "but I believe if niggers were put on the boats that the fun would commence around her, as this is general talk all around and it would be the hardest blow to the unions they have had...they don't like them any how and from indications it would cause the dock hands to take action if they were used." ${ }^{68}$ August brought a dockworker riot in Fort William, Ontario with strikers building barricades and exchanging fire with police. Local authorities sounded the alarm that open rebellion was at hand. The strikers held out without support until the arrival of military units and a declaration of martial law. The strikers were recent Greek immigrants and particularly unpopular among native-born dockworkers. Accused of not listening to reason, officials and local unions portrayed the violence as the Greek workers supposed "thirst for blood." Though other strikers could return to work, Greeks were not rehired. ${ }^{69}$ Lake Seamen's Union locals had fragmented in Buffalo over the desire to exclude Polish and other Eastern European immigrants from being members. Even when eager to join the union, immigrant sailors were viewed as merely being part of the vessel owners' tactics to push out native-born sailors. $^{70}$

During the fall, demand for ore increased and a bumper crop of grain flooded the market at record levels creating great need for tonnage. ${ }^{71}$ Compared to the meagre sums the sailors' union could provide to strikers, the surge of new berths drew even union stalwarts away. Allied unions provided some contributions, but the sheer number of strikers on the Lakes made their efforts insufficient to meet demand. In November, the union slashed strike benefits for the winter months in

66 Operative Report, 2 May 1909, Box 4, OWPDC-BGSU.

67 "Dastardly Attempt," DEH, 28 May 1909.

68 Operative Report, 6 May 1909, Box 4, OWPDC-BGSU.

69 "Dock Strikers Shot By Police," TB, 11 August 1909; "Ft. William, Ontario Under Martial Law," MDMJ, 13 August 1909; "Order is Restored," DEH, 13 August 1909.

70 "Men Will Return to Work on Docks," CPD, 13 August 1909.

71 "Ore Shipments Break Record," DFP, 6 September 1909; "Many Boats Being Built," DEH, 6 September 1909; "Moved More Than 7,000,000," CPD, 5 October 1909. 
order to keep some labour halls open. After spending $\$ 50,000$ since May, they now struggled cover expenses. ${ }^{72}$ The Lake Carriers', on the other hand, declared victory in its 1909 Annual Report and that the successful drive for the open shop principle had demonstrated its necessity going forward.$^{73}$ For all intents and purposes, the sailor strike ended at the close of navigation in 1909 existing only as a symbolic effort until it officially ended in $1912 .^{74}$

\section{Defeat and Its Aftermath}

At the start of the 1909 strike the International Sailors Union had counted 25,000 members in the US and Canada through its Lake Seamen's Union affiliate. In 1910 it fell to 16,000 with most of the losses coming from the Great Lakes. That number continued to stagnate for decades to come. While a core of members remained, their influence proved limited. The longshoremen, though they managed to avoid the LSU's fate, also found themselves isolated and retreated from any further confrontations even as they lost work to automation and non-union labourers. ${ }^{75}$

The years after the strike brought further changes to the Lakes shipping industry. Within a few years, five large fleets dissolved due to financial misadventure. The Hawgood fleet collapsed in 1913 beause of overextension and insolvency. That same year the Gilchrist fleet merged with the United States Transportation Company. The Mitchell, and Wolvin fleets joined the powerful new Interlake Steamship Company of the mining firm Pickands, Mather Company that was managed by Harry Coulby. Though independent fleets such as Hutchinson, Tomlinson, and Wilson Transit survived and prospered, the days of "wild tonnage" ended as the transport system became increasingly structured and rationalized both in cargo and labour. Even during the First World War, when so many industries either nationalized or put aside their interests to serve the war effort, the Lake Carriers' gave only the ground it had to. It would balk the US federal government both during the war and into the 1920s as the newly formed US Coast Guard attempted to have a greater say in Great Lakes navigation. ${ }^{76}$

72 Statement by Edward Stack and Michael Casey, 23 November 1909, Box 2, Folder: Letters About the Strike, 1909-1911, ISU-DPL.

73 Annual Report of the Lake Carriers' Association, (Cleveland: Lake Carriers' Association, 1909), 2.

74 Victor A. Olander to D.S. Alexander, 12 June 1910, Box 2, Folder: Letters About the Strike, 1909-1911, ISU-BHC-DPL; "Says Report is not True: Official Denies that Strike of Marine Firemen and Cooks is Ended," DNT, 27 April 1911; Michael Casey to Robert Clarke, 29 December 1911, Box 3, Folder: Milwaukee, 1911, ISU-DPL; House Committee on Investigation of United States Steel Corporation, Hearing on United States Steel Corporation, Part 45, $62^{\text {nd }}$ Congress, $2^{\text {nd }}$ sess., 1912 , 2995-3028.

75 Paul F. Brissenden, Employment System of the Lakes Carriers' Association Its Bulletin No. 235 (Washington, DC: Government Printing Office, 1918) 20-27, 153.

76 "Gilchrist Boats Seized," SSMEN, 21 January 1910; "48 Gilchrist Vessels are Sold at Auction," DNT, 7 March 1913; "Gilchrist Fleet is Nucleus of Merger forming Interlake Steamship," Grand Rapids Press, 26 April 1913; Brissenden, 32-33; Russell, 78. 
The Strike of 1909 was a turning point for the Great Lakes bulk transport network and its evolution into a structured and corporatised system. The path to the conflict passed through three earlier crises that marked the divergence of labour and vessel owners. Sailors continued to attempt to recapture the traditional roles of an earlier era of shipping and in doing so fostered the divisions that undermined these efforts. Vessel owners found solidarity through a coercive form of shared self-interest that produced a modern managerial system. Labour's muted response in the aftermath of the terrible storm of November 1913 and the heavy loss of life meant that, truly, the iron boats and their wooden men now ruled the waters. 